\title{
Politics of Participation-In Search for Deliberative Governance in China
}

\author{
Zaijian Qian*, Shitao Huo* \\ Political Science Department, University of Wisconsin-Baraboo and Sauk County, Baraboo, WI, USA \\ Email:shitao.huo@uwc.edu
}

How to cite this paper: Qian, Z. J., \& Huo, S. T. (2017). Politics of Participation-In Search for Deliberative Governance in China. Open Journal of Political Science, 7, 257-266. https://doi.org/10.4236/ojps.2017.72020

Received: February 16, 2017

Accepted: April 11, 2017

Published: April 14, 2017

Copyright $\odot 2017$ by authors and Scientific Research Publishing Inc. This work is licensed under the Creative Commons Attribution International License (CC BY 4.0).

http://creativecommons.org/licenses/by/4.0/

\begin{abstract}
A rising enthusiasm among general public to participate the government businesses has become a noticeable development in China's recent history. Authors have observed government sponsored programs to endorse policy feedbacks from society; we have also witnessed spontaneous actions by individuals and social groups to involve in the debate and discussion on varies socioeconomic issues and problems, mostly through direct contact with government agencies, or mass media and social media networks. It is through open, fair and public deliberation over large and small issues in all sectors of government institutions that the quality of government governance has been steadily improved. This in return galvanizes further changes in the political institutions, processes and policy making outcomes, and contributes to a higher echelon of legitimacy for the regime. Politics of political participation through democratic deliberation in China is a logical result of a permanent transformation in decades-from the change of political rhetoric in nation's Constitution, to amazingly expanded economy, profound restructured social stratifications, redistributed wealth and assets, enormous number of affluent middle class population, and increasingly fledged agents of civil society. We argue that the growth of massive participation in government businesses has not only proved to be realistic to its governance, but also well serves an alternative mechanism for oversight of government behavior. Deliberative democracy is useful because it is a complementary agent to electoral democracy.
\end{abstract}

\section{Keywords}

Political Participation, Deliberative Democracy, Middle Class, Coercion, Cooperation, China, Politics of Election and Deliberation 


\section{Introduction}

In contemporary Chinese society, many have observed a rising enthusiasm among general public to participate the government business processes. The politics of participation in the areas of judiciary, legislative as well as executive branches of the governance has become a new normal of everyday life.

When evaluating an earth shaking transformation in China's recent history, lot of credits have been attributed to its paramount agenda in economic growth. However, the profound socioeconomic changes have also caused inadvertent yet, permanent evolution in the nation's political life. As result of a restructured social stratification, redistribution of social wealth, and a steadily growing middle class at about 340 million prosperous citizens (China Business Review, 2009), general public has started testing once-to-be dangerous water in government business swamp.

It seems that government power has increasingly shown its growing penchant of tolerance. The old fashioned governance through coercion has given way to much willingness for cooperation. A great number of socially articulated issues, together with many government sponsored topics, have been successfully managed to put on the public tables for deliberation. Increasingly transparent policy making processes have educated and taught everyone that successful government governance can be reached by welcoming public participation.

\section{It Is Your Business so as Mine}

\subsection{Judicial Retrials}

One of the recent judicially repealed cases has resonated how a criminal justice case has led to extensive public deliberation that contributes to a different result in the government retrial. The judicial case of Nie, Shupin, who was sentenced to death penalty for the alleged rape and murder of a women, and was executed twenty-two years ago, has been recently repealed by the State Supreme Court as an wrongfully identified perpetrator for Wang, Shujin, a serial killer, and the real criminal in this case. Similarly, another social deliberation on the "lei, Yang" case revealed the excessive use of police violence causing the death of a college graduate student. Most recently, several other criminal cases have been put on retrial with opposite adjudications as a result of socially participatory deliberation.

The fact the overturning of judicial cases rarely happened until recent time demonstrates the improved sense of public participation in government decisions, the improved tolerance level to appeals in current judicial proceedings, and the willingness of government to work with non-governmental articulations (Xinjing Journal, 2016). These also helped unveil the police abuse of violence and to express the concerns about possible ripple effect of government wrong doings over the general public safety (Xinhua News Agency, 2013). Overall, the real astonishing fact of these judicial cases is not how the case were overturned, it is the national attention and extensive deliberation among general public make 
them conspicuous topics. Obvious take away from reviewing these successful retrial cases could include the rising public enthusiasm in participating government judicial decisions, the real social pressures in checking and correcting government businesses, and ultimate objective for social justice-your business is mine as well.

\subsection{Executive Policy Making}

More cases of public participation in executive policy making process through extensive deliberation on fundamental socioeconomic issues have occurred on regular basis.

On local as well as provincial levels, township and city residents are able to sponsor the agenda for issues deliberation. An estimated 453,000 meetings were held in the year of 2004 alone at village level for deliberation that covers wide spectrum of issues such as budget, land contract, water supply, school site, waste management, migrant workers' income (China File, 2011-2016).

Ground rules and procedures were worked out between government and citizens as guidelines for the decision making. For example, first, a meeting can be called if 15 signatures are collected; next, participants to the villages' meeting are selected based upon both application and self-nomination; thirdly, all policy options are encouraged to lay on the table for deliberation, pros or cons; and finally, upon picking final option, the government will have to explain the policy decision with justification and all necessary supporting reasons to the public (China File, 2011-2016). Some of the formats and functions of these participatory governance practices seem close to the town hall meeting and its referendums in the USA.

\subsection{Legislative Deliberation}

Nothing could be more significant than a law passed by the National People's Congress in regards to public hearing system in 2000 (Jiang, 2000). A quintessential example of political reform, this system requires public hearing over administrative laws and regulations. Therefore, the general public has a legal opportunity to not only learn, but also express their opinions over their day-to-day interests of life such as educational fees, fireworks restrictions, and air fare regulations.

The Personal Income Tax Law of 2007 presents an outstanding case, where National People's Congress Standing Committee promoted a draft for public deliberation before it settled with a final version. Based on massive and national wide discussion, debate, hearing via academia, mass communication and social media, the threshold of original tax rate was raised from 800 RMB to $1600 \mathrm{RMB}$, (RMB, Hu, 2007) and it was passed by the National People's Congress as Tax Law.

\subsection{Institutionalized Attempt for Deliberative Democracy}

Deliberative Democracy in Chinese language has its derivative meanings in 
consultation, examination, discussion, dialogues, and explicit rhetoric inclination towards debate for negotiations and compromises.

The concept of Deliberative Democracy and its political utilities has been officially recognized and promoted since the 18th CPC National Congress and the Third Plenary Session of the 18th CPC Central Committee (Xinhuanet, 2013).

Upon commitment to eventual goal for Democracy, the consensus on alternative approach towards democracy seems to have reached among Chinese academia as well as government, that is a much needed and applicable model will work for Chinese society at a much cost benefit and efficient approach. And that is Deliberative Democracy. First, electoral democracy is not part of Chinese tradition, and will need time to construct; second, electoral democracy doesn't answer the question of how government is making its decisions; third, with popular participation in deliberative process in policy making and implementation, real sense of representation will function over the power of political elitism (Yu, 2013).

Some have observed in contemporary China, regime backs down in the face of massive social discontent made China a different model than Russian's. Many empirical cases seems to showcase the democratic in natured practices have been developed through regime accountability. These include new programs and policies for migration of rural millions to cities; to strike unsafe milk and crooked officials, ease rural poverty (Roskin, 2016) and of course, the increased debates and deliberations on wide variety of social issues resulted in fundamental policy changes in tax policy, one child policy, and the crack down on corruptions.

\section{Deliberative Democracy in Political Participation}

One common consensus about democracy as concept and system is the scope of participation of citizens in the political process, from election to governance. Modern democratic system allows political parties to mobilize majority of citizens along party lines to win the elections. The winning of election starts governance under party's agenda that supposedly represent the expectations of their political supporters.

By definition, winning of elections and controlling governance can be legitimized and reasonable only when greater number of citizens becomes essential part of the processes. A democratic representative government, therefore, has been the result of politics of participation.

Some has viewed deliberative democracy as one of most real and effective approach to the practice of public participation, as it provides citizens the opportunity to watch and urge the politicians to turn their words into reality after the electoral process is over. Therefore, the politics of participation continues as integrated and consistent process as what "Democracy" is originally meant for as forms in decision making, organization and governance (Manin, 1987; Carcasson et al., 2010; Gutmann \& Thompson, 2004).

We argue that despite its overall democratic system being uninstitutionalized, deliberative democracy at macro as well as micro levels in China's government 
governance process is existing, and being promoted to a positive direction.

Chinese government has proactively pursued cooperation with greater tolerance to include general public and its voices in its governance. This statement has been based on our observation over recent changes in China, and is justified by the empirical cases listed in this writing, and appeared in widely accessible media networks. For more or less, the Chinese stories exemplify four core components of what a deliberative democracy entails-inclusion, political equality, reasonableness, and publicity (Young, 2000). Some has predicted that due to its current political system and historical background, a deliberative democracy may become a much suitable and sustainable model for a successful Chinese political transition (Qian, 2016).

\section{Peeling off the Chinese Onion}

Deliberative democracy in China does not happen by accident. It becomes a reality right as result of its ongoing changing current political system and deeply embedded historical background. Let us peel off the Chinese onion layer by layer and manage to figure out the embryos that spawn the changes.

\subsection{Rising Political Legitimacy}

The UN has recognized the undisputable contribution China has made to the global human society by lifting 700 million of its population out of poverty in the past 30 years (The State Council, 2017). Moreover, the better opportunity of employment, consistently improved quality of living, and overall socioeconomic conditions in China, have been reflected in a recent international survey as highest ranked country in satisfaction of national conditions, and in views of current economic situation with followers in far behind distance except Vietnam (Pew Research Center, 2014).

Much expanded economy and incredibly improved living conditions have made Chinese the happiest (89\%) in such survey comparing with 43 other countries (Simmons, 2014). Many of the surveyed Chinese people believed their conditions are going to get better; economy will continue to improve; and their next generations are to be financially more affluent than their parents.

Years of economic growth and its strong and substantive impact upon the life of people has definitely contributed to the much improved legitimacy of, and people's confidence with the Chinese government.

\subsection{Constitutionalized Rights for Private Property}

One fundamental reason for such extensive support of government among Chinese public has been the result of a landmark transformation of nation's constitution in acknowledging the property rights of individual citizens. Protection of citizen's property rights has been clearly added with general consensus in the nation's Constitution sine 1982 (Chen, 2004). Twenty-five years later, a monumental Property Law was formulated to define the personal property ownership, the utilities of properties and protection of the rights of property owners (The 
State Council, 2014).

Such incremental yet determinant change in CCP government to embrace the reality and trends of individual rights essentially represented by their property ownership testifies that the success of transformation in economic areas would inexorably lead to moral as well as institutional progress towards humanity. It simply means how a dominant party can even risk loosing its logical sense of Communist Manifesto for a much desired political legitimacy; and such transformation replicates the similar revisionist moves by European social democratic parties back in 19 Century.

A CCP government with much revisionist platforms and institutions has helped the nation to reach remarkable success in both economic and social transformations. Recognition and protection of private property in China guarantees popular support of government legitimacy in the nation's future adventures.

\subsection{Expanded Private Entrepreneurs and Civil Society}

As result of economic expansion, increased economic freedom in private ownership, and occurrence of affluent social groups, indispensable agents for private sectors as well as civil society have all come into being.

Social forces have increasingly seen much of the growth in private entrepreneurial sectors. World Bank's research shows that in the past 20 years since the middle of 1990's, entrepreneurs, not government control, are primary source of China's growth. Chinese private businesses, such as Alibaba, Baidu, Wanda, Huawei, Lens Technologies and many other rapidly emerging companies have spawned over 40 million in numbers, and started challenging national as well as international rules of business games (Chatham House, 2015). Another remarkable data finds, while state owned and non-state owned enterprises each made revenue of 4 trillion respectively in 2000, the total private businesses' revenues jumped 18 times while state owned business only increased six fold by 2013 (Tse, 2016). Chinese government announced that private enterprises were responsible for over 60\% of China GDP by the yare of 2014 (People Net, 2014). In east coast areas, the private enterprises accounted for $80.81 \%$ of all revenues in most recent times (Tan, 2016).

Backing up by financial resources, together with policy for absorbing non party members into government business circle, business celebrities have taken responsibilities for governance. By 2012, billionaires have started becoming representatives to People's Congress: top $17 \%$ of these reps are much richer than the entire US Congress people and the president, entire Supreme Court members in combine (Hoogewerf, 2012).

A third social string beyond government and private sectors lies in rapid growing civil society. You may think how this could even be real in a less politically active nation. However, as we-the authors and all ordinary Chinese people -have experienced and observed, a living civil society are real part of everyday life in China today. Take religion as an example. According to most recent pub- 
lished CIA World Factbook, the total religious population of China has reached amazing 655 million plus people as of 2016, which include Buddhists, Christians, Muslins, Confucianists, and Daoists (CIA World Factbook, 2016).

A wealthy population in China has taken the lead in international travelers since 2014, surpassing the US by 54 billion dollars with only $6 \%$ of its total citizens. And the number of Chinese International traveler has reached 120 million by 2015 (Reed, 2015). The free choices of daily activities are also souring in migrant workers across regions and borders, and in even faster pace of free flow of FDI and international students all over European, North American and other developed states.

Nothing could be more exciting than the explosive rising of social interest groups all over the country. People of all walks have managed to find others sharing same interests, and the ways to entertain, express, articulate, and enjoy their life. Dancing on the square in both urban and rural areas, chess and cards clubs, literature, music, art and artifacts education in senior citizens' universities, art performance groups, to name just a few among all others. And all of these groups are non profit and socially self-reliance interest groups. With social media tools, authors experienced in-depth discussions on varies social political issues, including harsh criticism to historical as well as current policies and political leaders.

Up to this point, we seemed to have depicted a clear scene of root causes, the logic and existence of participatory politics via public deliberation in China.

\subsection{Historical Legacy in Remonstration}

However, the regime in transition has no fully fledged institutions to automatically respond to the articulation from society in a free and confident approach. It is rather a bit of challenge to the traditional mentality of governance. With no appropriate mechanisms channeling state and society, yet a lot of sense of urgency to ease up potential spark to mob uprising, a historical legacy of remonstration was also brought into practice (Liao, 2014). It is also believed that Mao's revolutionary legacy of "Mass Line", the growing reported public security incidents due to corruption and bureaucratic mal-management, and out of date old fashioned top-down management approach, all forced government to opt alternative yet effective way for governance (Rosenberg, 2006).

Remonstration was a tradition developed since ancient royal dynasties where emperors tolerated dissuasions from his loyal senior advisors on civil and military strategies. Mass Line is one of Mao's revolutionary principles that brought unexhausted material and moral support from nation's majority for the final success of his party and army.

It turns out the historical background and the tradition of one party rule, have reconciled with changed economic and political conditions in the post revolutionary society in China. All of which have contributed to a brand new strategy motivating the public participation. With modern technology in internet and social media, government at all levels, welcome public input for their policy 
making and implementation. Such political experimentation proves to be pragmatic, and sustainable in the government governance. Functionality wise, it works; and theoretically, it is useful.

The used to be coercive policy making and implementation processes have gradually, yet steadily given way to reciprocity and cooperation.

\section{Missing Links in Electoral Democracy?}

Let us discuss the theoretical usefulness of Deliberative Democracy for the government governance in China and its implication for democratic practices. First, in conclusion, a government with much improved legitimacy will no longer fear challenges to its governance. Yet, for the sake of sustainable stability, open mindedness with no change of power structure, the institutions will need to be reshaped to include plural voices and interests. The general public has the vested interests in helping government to continue transforming along a positive direction, and they learn from social practices how to reach out to the government decision making without pushing it too hard. Thus, an inclusive, open, equal and reasonable institutional devise has been constructed as combined effort by both government and society, which sets the ground for reciprocal and participatory processes for governance.

Second, Deliberative Democracy puts political participation under scrutiny. Now a question arises as corollary of the logic in western style of electoral democracy. Does democratic elected government warrant its essential nature of representation?

This question can be answered by two folds of analysis. First, western electoral democracy is legitimized by the scale of participation. Believing the less political participation, the less democracy (Verba, 1972), American party' machines have given their position to direct primary, followed by rounds of political campaign finance reforms, just to maintain the very essence of a representative government. Despite all the efforts, the lower turn out rate during election days in America and others (Pew Research Center, 2016) has challenged the legitimacy of political representation of government at all levels in these western democracies.

The second set of analysis to above question seems to be much terribly relevant-the even lower participatory rate AFTER the elections. With extremely smaller group of citizens' attention, or nearly zero impact of public opinions (Glens \& Page, 2014) on government governing process, the authentic essence of democracy has been greatly compromised. American political system relies on the checks and balances, and media for oversight of the government performances. When Washington DC is under one party's rule, and or when media lost its professional ethics as we have witnessed in the overwhelmingly failed polls in the last presidential elections, the chance the general constituencies can be taken as hostages for partisan/corporative/bureaucrats complex's interests could be astonishingly real and tragic. Did we approve George W. Bush's unilateral military invasion in Iraq? When trillions of tax dollars were invested to 
rescue Wall Street financial tycoons, and paid for their bonuses, did Barack Obama ask about tens of millions of those living in poverty in Kentucky Mountains and Rust Belt how to fetch their next meal?

However, China's experiments in deliberative problem solving for governance may provide a possible alternative for public oversight of government businesses - a complementary mechanism for democratic operation. With increasingly wide scale of participation in the governance processes, facilitated by the open information and free and fair deliberation, the government is held accountable by participatory public for its behavior in policy making and implementation, regardless of campaign promises or political rhetoric. Given time for political institutions to fully improve, a real democracy legitimized by mass participation will probably be accomplished with all the links in its functionality-majority ruled election, deliberative governance, and all social powers' oversight.

\section{References}

Carcasson, M. et al. (2010). Communication Studies and Deliberative Democracy: Current Contributions and Future Possibilities. Journal of Public Deliberation, 6, Article 8.

Chatham House (2015). The Royal Institute of International Affairs. The Rise of Private Enterprise in China, 16 July 2015.

Chen, J. F. (2004). China Perspectives [Online]. The Revision of the Constitution in the PRC, 53, May-June.

China Business Review (2009). USCBC on 1 January.

China File (2011-2016). A Project of the Center on U.S.-China Relations at Asia Society. Center on U.S. -China Relations, 4.

China File (2011-2016). pp. 4-5.

CIA World Factbook (2016). China Demographics Profiles 2016, 8 October.

Glens, M., \& Page, B. (2014). Testing Theories of American Politics: Elites, Interest Groups, and Average Citizens. Perspectives on Politics, Cambridge University Press for AP.

Gutmann, A., \& Thompson, D. F. (2004). Why Deliberative Democracy? (pp. 3-7). Princeton, NJ: Princeton University Press.

Hoogewerf, R. (2012). Huren Report. 30 November.

Jiang, Z. M. (2000). Legislation Law of the People's Republic of China (Order of the President No. 31).

Liao, R. (2014). China's Experiment with Deliberative Democracy (p. 4). Center on US-China Relation, May, 27, 20.

Manin, B. (1987). On Legitimacy and Political Deliberation. Political Theory, 15, 338-368.

People Net (2014). Modernization of State Governance, State Ownership vs. Private Enterprises - Walking with Two Legs. URL (Last checked 25 February 2017) http://theory.people.com.cn/n/2014/0825/c388253-25532859.html

Pew Research Center (2014). Global Attitudes \& Trends. 9 September: 87\% in National Conditions, and 89\% in Economic Situations; Vietnam has been copying all its developmental strategies and socioeconomic policies from China.

Pew Research Center (2016). The USA Lands 31st among the 35 Countries, Most of Them Are OECD Developed and Democratic States. 2 August. 
Qian, Z. J. (2016). Deliberative Democracy-In Search of a Path to Open Operation of Public Power. Journal of Probe, No. 5, 42-48.

Reed, Dan, (2015). Chinese Extend Lead as the World's Biggest Spenders on Foreign Travel. Forbes, 7 January 2016; Travel China Guide.

$\mathrm{RMB}=$ Acronym for Ren Min Bi, the name of Chinese dollar. Hu, J. T. (2007). Decision of the Standing Committee of the National People's Congress on Amending the Individual Income Tax Law of the People's Republic of China. (Order of the President No. 66).

Rosenberg, S. (2006). Human Nature, Communication, and Culture: Rethinking Democratic Deliberation in China and the West. In E. J. Leib, \& B. He (Eds.), The Search for Deliberative Democracy in China (pp. 77-112). Basingstoke: Palgrave Macmillan.

Roskin, M. G. (2016). Country and Concepts: Politics, Geography, Culture (13th ed., pp. 282-283). Pearson.

Simmons, K. (2014). China’s Government May Be Communist, but Its People Embrace Capitalism. Pew Research Center, 10 October.

Tan, L. (2016). Secretary of Department of Chinese Industry and Commerce. Report on Chinese Private Enterprises Top 500, 25 August 2016.

The State Council of the People's Republic of China (2014). Property Law of the People's Republic of China. 23 August.

The State Council of the People's Republic of China (2017). Top News. China Issues White Paper on Poverty Reduction, Human Rights. 17 October. URL (last checked 25 February 2017)

http://www.chinadaily.com.cn/china/2016-10/17/content_27081127.htm

Tse, E. (2016). The Rise of Entrepreneurship in China. Forbes, 5 April.

Verba, S., \& Nie, N. H. (1972). Participation in America: Political Democracy and Social Equality. New York: Harper \& Row.

Xinhua News Agency (2013). 13 May.

Xinhuanet (2013). Decision of the Central Committee of the CCP of China on Deepening Major Reforms. 15 November. URL (last checked 25 February 2017) http://news.xinhuanet.com/english/china/2013-11/15/c_132891922.htm

Xinjing Journal (2016). 12 December.

Young, I. M. (2000). Inclusion and Democracy (pp. 31-33). Oxford: Oxford University Press.

Yu, K. P. (2013). Several Issues on Deliberative Democracy with Chinese Characteristics. CPCnews.cn, 23 December. 
Submit or recommend next manuscript to SCIRP and we will provide best service for you:

Accepting pre-submission inquiries through Email, Facebook, LinkedIn, Twitter, etc. A wide selection of journals (inclusive of 9 subjects, more than 200 journals)

Providing 24-hour high-quality service

User-friendly online submission system

Fair and swift peer-review system

Efficient typesetting and proofreading procedure

Display of the result of downloads and visits, as well as the number of cited articles Maximum dissemination of your research work

Submit your manuscript at: http://papersubmission.scirp.org/

Or contact ojps@scirp.org 